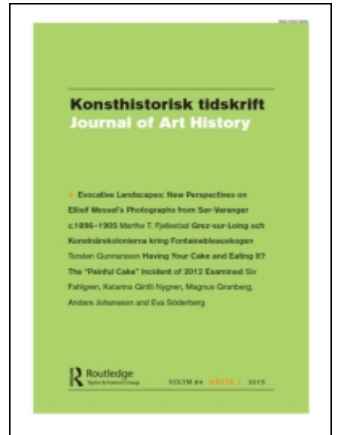

Konsthistorisk tidskrift/Journal of Art History

\title{
Having Your Cake and Eating It? The "Painful Cake" Incident of 2012 Examined
}

Siv Fahlgren, Katarina Giritli Nygren, Magnus Granberg, Anders Johansson \& Eva Söderberg

To cite this article: Siv Fahlgren, Katarina Giritli Nygren, Magnus Granberg, Anders Johansson \& Eva Söderberg (2015) Having Your Cake and Eating It? The "Painful Cake" Incident of 2012 Examined, Konsthistorisk tidskrift/Journal of Art History, 84:1, 55-70, DOI: 10.1080/00233609.2014.981206

To link to this article: https://doi.org/10.1080/00233609.2014.981206

曲 Published online: 10 Dec 2014.

Submit your article to this journal $\longleftarrow$

Џll Article views: 267

Q View related articles $\sqsubset$

View Crossmark data ־ 


\title{
Reflection
}

\section{Having Your Cake and Eating It? The "Painful Cake" Incident of 2012 Examined}

\author{
Siv Fahlgren, Katarina Giritli Nygren, Magnus Granberg, Anders Johansson \\ and Eva Söderberg
}

\section{Prelude}

On 15 April 2012, Moderna Museet (the Museum of Modern Art), Stockholm, Sweden, celebrated the World Art Day and the 75th birthday of Konstnärernas Riks organisation (the Artists Organization), by having a reception with Sweden's minister of culture Lena Adelsohn-Liljeroth present. Five artists had been asked to create birthday cakes for the occasion. At the event an artwork in the form of a cake made in the likeness of the body of a caricatured black woman was served, cut up, and eaten, while the artist, masked as the cake's black head, screamed, as can be seen in a film clip on Youtube. ${ }^{1}$ This relational and contextualizing artwork was made by the selfproclaimed antiracist artist Makode Linde. The "Painful Cake," as he calls it, can be seen as part of Linde's larger project "Afromantics" where he uses the blackface figure in different historical, cultural, and religious contexts.

The name "Afromantics" reflects, says the artist, "on the romanticized, supposedly positive stereotype of the happy, grinning 'pickaninny' (a caricature of black children) that appears on all the artwork, and is meant to show the connection between those stereotypes and the more vicious ones, all connected in the same system of oppression." ${ }^{2}$ In the afromantic gallerie of Linde the blackface is painted on Western icons: Beethoven, Betty Boop, the twelve disciples, the Queen of Sweden, a teddy bear et cetera. In "Painful Cake" the blackface appears on the artist himself, lending his own head to the body of a black Venus of Willendorf with an obvious reference to Sarah Baartman (who was born in the 1770 s in South Africa and died in 1815 in Europe), the "Hottentot Venus" exhibited in freak shows in Europe between 1810 and 1815 who became an icon shaping the Western image of black female sexuality. After her death, the Musée de l'Homme in Paris removed her skeleton and pickled her brain and genitals in jars. The remnants were displayed in the museum until as late as $1985 .^{3}$ Sarah Baartman's story, and the power of its re-telling, has led to her being appropriated as a focal point for discourses on gender, race, and colonialism and specifically Western representations of black female sexuality.

Images of "Painful Cake" went viral instigating heated debates in Sweden, with international reverberations in broadcasts by the $\mathrm{BBC}$ and Al Jazeera. The National Association of Afro Swedes demanded the minister's resignation, as did hundreds of viewers across the world. These sentiments echoed in an open letter to the minister posted on MsAfropolitan: 
The moment that cake was presented; the moment that cake was eaten; the moment that cake caused joy and excitement, reopening the marvel that white Europeans felt at exploiting African women's bodiesspecifically, the sexualized celebration, the entrapment, the cutting of the genitalia of the Sara Baartman-like black body, the ethics of the artist comes into serious question...

Thus, there are some important intersecting trajectories between the exhibitions of Sarah Baartman and "Painful Cake" raising questions about the artwork promoted by the Museum of Modern Art and how the exhibition existed in a state of suspended separation; not only synchronically separated, from the geographical context of the practice of clitodirectomy, but also diachronically separated, from the historical constitution of this object of the Western gaze.

Hundreds more registered outrage and disgust on social media. When an artwork travels from one scene to another, the nature of the responses also changes. This makes it urgent to discuss "Painful Cake" beyond its strictly artistic value. In our view, some points of contention in these debates (which, of course, form parts of the artwork; art, just like any other relational, social entity, is principally boundless) amount to complex articulations of pivotal problems in critical thought concerned with racism as well as sexism. In this article, we white researchers currently working in an interdisciplinary project dealing with normalization and gender theory, and not art scholars - will examine some of our reactions to the work in order to grasp some aspects of these articulations, or, in the words of Laurent Berlant, analyze how "aesthetically mediated affective responses" may "exemplify a shared historical sense." Without aspirating to provide a comprehensive study, neither of the artwork nor the debates, we will discuss some of their affective and theoretical resonances.

Despite its critical impulse, modern Western art is intimately entwined with Western global hegemony and dependant on its capitalist economy. As both Theodor Adorno and Pierre Bourdieu have pointed out, albeit in different ways, it was through the fact that they were commodities, integral to capitalism, that modernist artworks received the freedom of also being something else, including the possibility to resist the commodity form and bourgeois norms. ${ }^{6}$ It is thus, and even more so since the advent of postcolonial theory, impossible to write a heroic-revolutionary history of art. Art has always been part of racist, sexist Western imperialism. Gaugin's exoticism and Picassos interest in African masks are racist. And yet, they are simultaneously important critiques of Western stereotypes. They may even be regarded as openings, however small, to "the other."

Today, art often reflects on and tries to exploit its own complex relations to society and politics. The cake incident is such a contextualizing and relational artwork. This is important since no predetermined line can be drawn between art and life, between an artwork and its reverberations, among visitors, in the media, in politics, and so forth. Art never escapes this element of contingency.

Among these contingent reverberations, we specifically want to consider two positions in the debate on the cake incident pointed out by McEachrane: that "Painful Cake" revealed racist structures in Swedish society, a point argued by most white writers, or conversely, that it reproduced racist and stereotypical images of blacks, as others, especially nonwhite commentators argued. ' The spokesman of the National Association of Afro Swedes, Kitimbwa Sabuni, for example, questioned the 
intentions of the Museum of Modern Art "to problematize female clitoridectomy and romanticized and exoticizing Western notions" (our translation). According to Sabuni the exhibition instead degraded women who had been subjected to a clitoridectomy. He also indicted the artwork as racist on account of its deployment of stereotypes and called for the minister of culture's resignation. ${ }^{8}$ So, although they certainly do not cover all the entries to the debate, we have one position suggesting that the artwork is racist, and another position, sympathetic to the artist, viewing it as an ironic play on stereotypes and thus antiracist.

Individualization of responsibility - blaming the minister, the artist, the museum - was a defining characteristic of the reactions we have outlined. This individualization could be regarded as part and parcel of today's neoliberal political framework, turning social and political issues into individual ones. In considering what the cake incident became, and what it could potentially have become, we thus find it important to dwell on some defining features of neoliberalism. In this article, a voice is raised for the importance of reading the ethical complexities of the happening. We will be discussing how political art in a neoliberal context has to fight hard to make political points, both because of individualization of responsibility and, more generally, because of art's dependence on representations that are unavoidably part of medialized power structures.

The aim of this article is to reflect upon what "Painful Cake" did - and did not do - in terms of how we experienced it. We have arranged it in the form of a triptych, beginning with a centerpiece that describes the artwork itself, and then moving to two side panels of situated and personal responses concerned with, respectively, emotions and representations. Finally - in order to mix the metaphorical use of esthetic metaphors completely - a reflexive coda discusses and summarizes the implications of the artwork as they regard the specific and situated contextual resonances we consider.

How did we react to the drama that we were following from a distance? What did the "cake incident" make us see? Linde's work raises questions concerning how to understand political agency and responsibility, as well as the possibilities and difficulties of critical art and thinking in neoliberal times. It raises questions about the possibility to individually and self-reflectively control the effects of the event of a work of art that has racist discourses as its working materials, as well as questions about antiracism and good manners (politely accepting the invitation to have a piece of cake). But it also raises questions about the society that we as researchers are part of.

\section{An autobiographical approach to shared experiences}

When we use the word "us" in this article, we mean five feminist gender scholars, three women and two men, located at a university in the North of Sweden. Our approach is autobiographic, drawing on five separate memories reflecting on the cake incident from a distance. By writing our memories down and reading them to each other, listening carefully to the details of the recollections, and discussing them, we created collective memories of the incident as lived experience. These collective memories are presented as a shared story about how we perceived the happening. Two collective memories are presented as the panels of a triptych. We use the rest of our shared experiences as ways of 
contextualizing and discussing the two memories in light of feminist critical theory. Theory is thus put to work "through our everyday lives with theoretical concepts that help us to think differently about how we come into being" as feminist gender scholars. ${ }^{9}$ By giving room for particular, local, and situated truths we hope to better understand how individuals are discursively constituted in particular embodied moments. Rather than an interest in the truth about what happened, in a collective biography like this we are guided by an interest in how we are discursively, affectively, materially constituted in particular moments such as the incident discussed here.

\section{A triptych}

A triptych (from the Greek adjective $\tau \rho i \pi \tau v \chi o s$, "three-fold") is a work of art that is divided into three sections, or three carved panels, which are hinged together. This hinged triptych with narrow panels closing like doors over a large center panel was a favorite form for Christian altarpieces from the Middle Ages onwards. ${ }^{10}$ The triptych panels were then sometimes folded shut, appearing as a unified piece, and sometimes displayed open showing a center image and two side images. The middle panel, called corpus, is the largest and it is flanked by two smaller related works. In the following we will use the triptych-metaphor to discuss this incident from different positions: corpus, side panels, and coda.

We will first of all present the corpus of this triptych, consisting of the actual event of eating the cake. At the same time some meanings of eating the other is explored as a background to the analysis of the effects of the artwork. Subsequently, two reflecting/mirroring panels will be presented, each of them offering specific readings of particular aspects of the incident and points of contention in the debate that unfolded after eating the cake. These two readings of the incident are written as monologues, taking different ethical positions on the event and its responses. That is, each reflecting position encounters the scene as an "I" though still in the form of a collective memory. The first panel analyzes some emotional responses that the incident evoked from a position of challenged whiteness. The other panel utilizes the concept of subalternity to analyze the politics of subjection articulated through the artwork. Finally, the drama pictured in this triptych is discussed in terms of its sociocultural significance in Coda - comments on the triptych.

\section{Central panel on "Painful Cake": corpus}

The scene is Stockholm's Museum of Modern Art, on Sunday, 15 April 2012. On the table, a huge cake, with a smooth shiny black surface, in the form of a caricatured African female body, sans legs. Naked, splayed on its back, it is composed of crotch, belly mound, and large pendulous breasts held by truncated stick arms, a row of neck rings. Where the neck rings end, a living human head rears up through a hole in the table. The head belongs to the kneeling body of a man. It is tricked out in exaggerated blackface - large white circles around the eyes, drawn-on cartoon red mouth, and pointed teeth.

Sweden's female minister of culture, Lena Adelsohn-Liljeroth, approaches the cake with a cake-slice in her hand. Cutting the first slice from the crotch, revealing a moist spongy red interior, the minister of culture performs what some has interpreted as a simulated clitoridectomy. The very cutting of the cake makes 
the reference to the Hottentot Venus mentioned earlier even more obvious. After Sara Baartman's death the name "the Hottentot Venus" was used for the plaster cast that was made of her body. Before that she was subjected to scientific experimentation; Georges Cuvier, the father of comparative anatomy, dissected her and preserved her brain and genital organs in order to highlight distinct racial and sexual differences between the African and the European "race." Baartmans' remains in Musée de l'Homme in Paris were "the bodily facts" that myths, stereotypes, and lies could be based on. For an interpretation of Baartmans body - as Janell Hobson puts it “requires that we 'read' this 'hard' evidence through an accepted ideology of racial and sexual difference."11 The head of the body moans and shrieks as with pain. A roomful of white Swedes, men and women, laugh and applaud. Cameras flash. In the photographs, faces appear alive, avidly entertained, as the minister feeds the slice she has cut to the grinning head. More people cut and eat slices of the cake body, dismembering it. The head moans, yells, and screams with each knife stroke.

The feelings of loathing and disgust that Linde's installation produced should not only be seen against the color of the illusory cake and slicing of what looks like a woman's abdomen (skin of black marzipan and redcolored insides) but also the fact that eating the cake imitates a violation of an ancient taboo against cannibalism or, more precisely, against anthropophagi, i.e. humans eating human flesh. There are many examples in our myths, folklore, and fairy tales of humans inviting other humans to eat human flesh or trying to outwit other humans for the purpose of eating them. Because of the reference made to motifs in myths and fairy tales and use of skin color in its specific contemporary context, a series of interlacing motifs are given multiple exposure in this artwork and thus produce feelings of recognition and alienation at the same time as existing interpretations are turned upside down, additional interpretations and reinterpretations made - just to make way for more interpretations at a later stage.

Among the multiple exposures given by the artwork are, for instance, the notion of socalled primitive humans eating human flesh found in white Western fantasies about "the Other," as well as "the Other" in the form of a consumer product. Such multiple exposures are not arranged in transparent and legible single layers but functions in such a way that the different elements of the artwork and the relevant incident are interlaced through and externally to the layers, thus increasing the interpretative potential.

From the very moment that the minister of culture took the cake spatula in her hand and cut a slice of the cake that resembled a black woman, she did, ironically and inexorably, fall into the same role as that of "the fearful Other" as portrayed in myths, fairy tales, fantasies, and popular culture. The cannibal pot has here been abolished. In the Swedish context, it is the cutting of the cake that almost in a carnivalesque reversal turns the minister into a cannibal, and the black woman into the victim of the white minister's "primitive" instincts.

However, ritual meals may also give power to the eaters. ${ }^{12}$ The Christian communion, for example, is believed to unite those who eat with that which is being eaten. However, a strong sense of belonging is also developed between those who eat together and share the body/ bread and drink the blood/wine. This approach reinforces the general impression of a united and affinitive white cultural elite eating the 
black human-looking cake and becoming a part of it and what it represents. Paradoxically, this creates a sharp line between whites and blacks but also between those who eat and are eaten at the same time as this is inexorably and brutally dissolved in the artwork.

The exposure of the black woman as commodity, combined with the mythical figurine Venus (Woman) of Willendorf and the iconic Hottentot Venus, is both an evocation of white people seeing black as a symbol of primitiveness and of ethnicity and diversity being portrayed in the mass culture as something that should be acknowledged and embraced, not least in a world promoting pluralism and diversity. In the article "Eating the Other: Desire and Resistance" bell hooks notes that the contemporary commodification of black culture by whites, based on a legacy of imperialist domination, is due to the enjoyment of an "Otherness" portrayed as more intense and satisfying than domestic phenomena not subject to such exoticization. Quoting the expression "Getting a bit of the Other," bell hooks considers what white men gain from having sexual intercourse with non-white women: "A step into the unknown world that promises transformation in the form of a rite of passage." "Getting a bit of the other" through "courageous consumption" may thus enhance the blank landscape of whiteness. ${ }^{13}$

According to bell hooks, it is not just about having sexual possession of the Other but also about exerting influence and experiencing a fundamental change by confronting the Other, which according to atavistic beliefs is where the spirit of a "primitive" human lies. In addition, bell hooks talks in general about preventing a post-modern sense of alienation by projecting "primitiveness" onto the Other, which hence becomes a place of dreams of abundance, wealth, and change at a deeper level. bell hooks refers further to the commercialization of the black identity, which has been utilized and promoted as an atavistic story, a fantasy notion of "otherness" that turns protest into spectacle and instigates an even stronger desire for "the primitive."14

There is the saying "you can't have your cake and eat it (too)," analogous to "you cannot have it both ways." However, the incident at the Museum of Modern Art in Stockholm shows that this saying is not always true. Rather the opposite! The Swedish minister of culture was invited to a meal "in the other world" and got "a bit of the Other," but the eating of the cake and the way in which the incident was filmed and spread across the internet will always stay with her, literally and figuratively. As it turned out, the literal became the figurative and vice-versa. However, in addition to the saying "you can't have your cake and eat it (too)" or not having it both ways, there is also the (literal) Swedish" you will eat this one day" related to the English "having to eat one's words" meaning "you will regret this." This usually involves a threat of future retribution by someone who has been violated or provoked. The consequence of eating the cake will be "chewed" over and over again for a long period of time.

\section{Left panel: emotions}

In this panel, the positioned "I" is a white female feminist scholar reflecting on the strong emotions the "Painful Cake" evoke in her. Coffee and cake is a part of the everyday life of those working for Swedish authorities; it is quite normalized. ${ }^{15}$ In this particular case, you could say that the minister of culture was, unknowingly, thrown into an unexpected, complicated, and unpredictable situation when she was offered to cut and eat a piece of cake in the 
shape of a black female body. Commentators nonetheless instantly condemned her actions and demanded her resignation. Of course, she, like everyone else, is responsible for her actions. At the same time this ascription of individual responsibility is in complete agreement with neoliberal ideas of individual autonomy, freedom of choice, and responsibility.

But no action can be interpreted based on the idea that freedom of choice is unlimited. The situation as well as history creates and defines the possible actions; as an individual one always act in specific contexts, which, to a certain extent, have helped shape the individual, and which, at the same time, are partly made up of and maintained by one's actions. Understanding culture as normalizing, ${ }^{16}$ the cake incident will also be able to say something about the place and the time in which the incident happens. At the same time, ideas of what is normal will always conceal or mystify the values and power relations behind it, thereby also where the responsibility lies. Therefore, the normalization process has to be demystified.

I could, by singling out the minister of culture as a scapegoat, by pointing the finger, conceal the shared responsibility of myself and other white, Swedish women that are acting as audience and who as such are also participants. S/he who points the finger takes on a responsibility of judging and condemning, but portrays her/himself as innocent. But who is innocent in a culture created by all of $u s$ and maintained by all of $u s$ ? Does not individualization instead lead to making the issue nonpolitical? When focus is placed on the individual's free will, there is a tendency to insinuate something about the individual participant's character or morality; she could or should have acted differently, she should be different. How different interests and options can be set against each other politically in complicated and complex relationships disappears out of view; the "situation" in terms of its time, place, history, and its contextually relevant discourses is underestimated. ${ }^{17}$ For example, everyday racism subtending the incident is occluded by this tendency toward individualization.

\section{Emotions of shame of what one is}

The cake incident is awful and appalling; it is difficult to reflect on without being filled with strong feelings. But what I feel is not mainly anger or indignation of the individual actions of the minister of culture - which, in addition, were not hers alone but shared by the others present. Rather, I am overflowing with feelings of shame and guilt. Despite it seemingly not having anything to do with me, I am ashamed of how the minister of culture behaved and I feel a sort of collective guilt. These feelings of guilt seem to originate in a painful identification with her behavior. I am ashamed on her behalf as well as my own, which in a way makes the feeling of who I am more focused.

Eve Kosofsky Sedgwick claims that the specific appearance of shame is based on culture and time and serves as a script for how we interpret the behavior of others. ${ }^{18}$ As a white, Swedish female gender researcher who is/should be aware of the equality and discrimination discourses of our time, to some extent, I identify (painfully) with the minister, and I am ashamed of the whole cake incident!

At the same time, shame makes the person feeling ashamed appear a little better than the person who caused the shame. ${ }^{19}$ I become dependent on resisting her to be able to move toward a "normality," which I do not really 
know if it exists at all, and if so where it can be found, but which I may need to create for myself in any case. In one swift move the feeling of shame creates and justifies this place of identity, the normal, good, white woman. The question is: does shame also justify the action? Sarah Ahmed describes whiteness as the backdrop against which social actions take place in a white man's world. ${ }^{20}$ How is this normalized backdrop put into focus and questioned?

But the cake cut and eaten was not only black. It was also in the shape of a female body. In a cultural background normalized in such a way that we do not even notice it, gender discrimination, such as (sexualized) violence against women, is also included. All women can be subjected to this type of violence, but it takes on different expressions in different contexts. Feminism is about taking on the "the pain of others". ${ }^{21}$ It is about allowing or making efforts to see the world from a different point of view, rather than the normalized point of view, and taking nothing for granted. To be a feminist is, as I see it, about asking yourself: what can I do? rather than acting normalized, saying: that's just the way it is! The critics have, rightfully so, asked where the feminists stand on this cake incident.

\section{Emotions of guilt, or taking responsibility for what one does}

If shame is related to questions of who you are, questions of guilt can also be related to questions of what you do. Based on Garrath Williams' discussion on finger pointing and its audience, I would like to conclude that everyone, regardless of whether we point our fingers or act as bystanders, have responsibility for the (discriminating) discourses and practices that are maintained historically and culturally. $^{22}$ There are no exceptions from this responsibility. Nor does individualization cancel out such a collective responsibility, although it does conceal it thereby rendering mobilization for change and resistance more difficult. A more complicated question is how a more justifiable responsibility can be taken? Could these emotions be mobilized for resistance and work for change instead of reproduction and justification?

\section{Right panel: screaming your head off: the subaltern speaks}

This panel also contains a strong emotional reaction to the cake incident by a female feminist scholar, the "I." The artwork is approached by giving some ethical reflections on the role of the subaltern in the cake debate through Gayatri Chakravorty Spivak's nowfamous question on whether the subaltern can speak. ${ }^{23}$ All in order to address the issue of the re-presentation of the subaltern, which I would say is very much in play in the performance by Makode Linde. In this perspective, issues of who is speaking, who is spoken of, and who listens are understood as a result, as well as an act, of political struggles. This means that we need to take into account not only the artwork itself but also the subsequent debate.

Spivak discusses the issue of representation and power by using the term subaltern. She uses the term when talking about different actions that construct women outside the West as lacking a subject position in the context of the Western hegemony. She argues that the marginalization of the subaltern consists of a double silence resulting from the lack of institutional representation and from the symbolic representation of the subaltern in, for 
example, art and philosophy. Spivak criticizes the use of the word representation since it ignores the two different meanings of the concept. She argues that the concept contains two different forms of rewriting the subaltern. Within representation understood as political representation there is the risk of making the subaltern an object of repression, in that this mode of representation does not confer on it its own voice, its own ability to speak, whereas representation as representing, in images or in signs, reveals a different form of objectification where the subaltern is produced by the viewer - in these images an identity is attributed to the subaltern not articulated by her. In the case of the cake scandal I would say that both of these processes of objectification were present.

Although Spivak emphasizes that there cannot be any real or authentic representation of the subaltern - since if she would speak in an understandable language, she would already have left the subaltern position - this must be seen in relation to her continuous and aporetic demand that this insight should lead to embracing of the impossible task of listening to the other, the subaltern. Not being able to find solace in either the play of representations nor authenticity, there is instead the continuous hard work of reading in search of the trace of the other, while being constantly aware of the difficulties involved. And it is these difficulties that show themselves in and around the "Painful Cake."

If we start with the artwork, we can see a slashed black women caricature on the table, a lot of white smiling female faces looking down at her while a black man (the artist) is giving her voice. Its manifest intention aside, it seems to me that this performance results in a representation of how subalternity actually works. That is, similar to Spivak's example of
$\mathrm{Sati}^{24}$ it is possible to read this performance as a manifestation of how black men, and white men and women, far too often feel authorized to speak on behalf of black women, though it is unclear from whence this authority derives.

Inspecting the diverse voices and viewpoints in the media in the aftermath of the cake scandal, the subaltern herself is silenced. And although we cannot hope to ever hear her authentic voice, the scream from the cake makes this lack of speech audible, and points to its contexts. In these debates those authorized to speak do so from positions legitimized by established, institutionalized arguments regardless of whether they oppose or favor the performance. The ones I noticed were (i) antiracist/postcolonial arguments; (ii) calls for accountability/responsibilization; (iii) various invocations of artistic freedom; and finally (iv) invocations of the right to freedom of speech. The range of possible combinations of these arguments circumscribe the positions taken up in the debates, while there is a striking absence of some other, equally established, positions and arguments that are otherwise usually authorized to speak. I am particularly thinking of the absence of feminist responses and claims of authenticity. The latter, though always deconstructable, are nevertheless, sometimes, essential for deconstructing other positions through their literalness. The questions of whether Makode Linde consulted any black women in preparing the performance, or considered whether it could inflict pain on black women, particularly on survivors of FGM, were never raised in these debates.

One has to venture outside the large media outlets to find these absent positions, arguments, and questions. The open letter to the cultural minister from the African women is already mentioned and on 19 April 2012 Shailja Patel, in the e-newspaper Pambazuka 
News, Pan-African Voices for Freedom and Justice, commented on "the missing ingredient in Sweden's racist misogynist cake":

It's tragic that in 2012, this basic tenet of any political art or advocacy is continually ignored by the entitled. And never more so than when it comes to African women and girls, the world's favorite target for rescue, the population everyone loves to speak for and speak about, but rarely cares to listen to. What makes this cake episode so deeply offensive is the appropriation, by both Linde and his audience, of African women's bodies and experiences, while completely excluding real African women from the discourse. It is pornography of violence. ${ }^{25}$

Another writer, who describes herself as a Sudanese-born American-raised bestselling author and a victim of genital mutilation, writes:

Let me ask those who see this as art right now. If it was Makode Linde's intention to make the world 'see' how racist we are by eating the genitals of the moaning cakethen why not make the cake look like a real African girl? An older woman with big bare tits wouldn't be having this genital cutting experience - a small child would. ('kolaBoof' April 20th 2012 http://www.owlasylum.net/ tag/kola-boof/)

So, approaching the end then: If a "true," nonrepressive representation is impossible, then should we, and how could we, speak anyway? Well I would say, if we were to take a cue from Spivak, who suggests subaltern studies to be a "strategic use of positivist essentialism in a scrupulously visible political interest," ${ }^{26}$ we would acknowledge that studying the subaltern subject will always be marked with ambivalence and absence, but it is also possible that existing institutionalized systems of representation are being questioned by persistent critique. Through writing workshops, Gordon-Chipembere has traced the trajectories linking Sarah Baartman to circumcised, immigrant West African women in New York. ${ }^{27}$
Gordon-Chipembere analyzes how the output of these workshops subverts the historically dominant Euro-American gaze on African women's bodies. The implicit racist and sexist language relaying the (a)historical Western narrative of Baartman is displaced as the participators enact a historically grounded "alter speech."

So, then, my answer to the question above is if the very ontology of being subaltern is silence, lack of voice, and agency, then I think we must ask further questions about the effects of this performance, questions that, in a strategically essentializing and stubbornly political way, address the following (even while knowing that it is impossible): Will it enable the empowerment of the ones represented? Will it enable the subaltern to take up another position, to talk? Does this performance inscribe the other in a subject position?

\section{Coda - comments on the triptych}

There are two things that really struck us reflecting on the cake incident and the panels of the triptych. First of all, it shows how racism still inhabits everyday life in Sweden, which should come as no surprise but is always portrayed as such in the media. Secondly, it shows the intractability of being antiracist. There is no straightforward way of being antiracist; good, well-meaning antiracism seems a very difficult task indeed. The artwork and its contextual resonances, such as the reactions touched on in the triptych, illuminate some repressed contexts, repressions that our present day liberal goodness depends on; the event thus exposes the contradictions of a facile liberalism.

Artists work with representations, with language and with images that belong to systems of power. The artist Makode Linde handles the 
material signs, the images of black men and women that racism has manifested itself through, and puts them in new contexts that make us see and react upon them. As a swiftly passing-by cliché of a Disney-film from the 1920 it is easy for a racist image to remain unnoticed, at least by a white audience, but placed beside a government minister on a plate it becomes visible. The happening at the Museum of Modern Art thus produced a series of effects by making a cliché salient by inserting it in a particular context. Everyday racism was painfully revealed and the effects of this revelation, among visitors, within the media and the public at large, seemed to raise the question: How should we relate to the stereotyped racist images that surround us?

The second striking feature was how the work and its reverberations were subjected to displacements beyond the control of the artist or anyone else; the evolution of the perception of the work took on a life of its own. Participants to the event, among them the minister of culture, were probably all wellmeaning antiracists. Yet even well-meaning antiracism can be problematic. Good intentions proved ineffectual since they form part of social contexts where antiracism is simply insufficient; of course, it is a "good thing" (we do not see cynicism as an alternative) but one must acknowledge that a practical racism subtends any symbolic antiracist gesture. Being part of this society is tantamount to being implicated in racist structures. A liberal democratic context and interpretative frame obscures this, positing racism as anomaly. And, moreover, critically acknowledging that we live in and reproduce racist structures is also insufficient, since criticism in itself reproduces that which is criticized, and even shame risks becoming yet another way to enhance white goodness. ${ }^{28}$ This becomes obvious in the reflected images of the triptych and in the artwork's brutal intervention.

\section{The (im)possibility of being responsible/taking responsibility}

Since the event took place within an art institution, marked as radical and antiracist, and since the cake was at the center of an explicitly antiracist artwork, courtesy demanded respecting the artwork by accepting the offer to have some cake, especially considering Sweden's "fika"tradition. One could call this a trap with two impossible alternatives. Should one reject an antiracist work of art, should one refuse to participate in the ironic gesture against clichés? It is the very impossibility of making an unequivocally good choice, that results. The images are there, ironic or not. And this is a rather important point - since it is such a highly integrated part of our self-conception as good Swedes that we reject racism. ${ }^{29}$ Or as one critical commentator, Kitimbwa Sabuni, stated in the newspaper Aftonbladet (our translation):

Sweden as a country has written itself out of
the history and the contemporary time
imprinted by racism that the rest of the
world functions within. Racist expressions
are therefore not considered problematical
in Sweden, since racism is not seen as a
problem here.

According to this view the artwork was racist in itself. This is also what many researchers have argued concerning antiracism, that it too, at least partly, reproduces racism. ${ }^{31}$ Criticism of racism has thus, in some of its contextual aspects, become a way for us with white skin not to acknowledge whiteness and its privileges. This is especially obvious in apologies given by governments to indigenous peoples. By pointing to the fact that we were racist the very apology becomes a way of creating an identity that is somehow beyond 
racism. ${ }^{32}$ Then one can "afford" the subsistence of racist clichés, and everyone knows that they are surrounded by quotation marks, steeped in "irony" and thus nonracist.

There is thus something problematic in enlightened, contemporary, "good" antiracism. It continues to represent the other from a position of power. The fact that it is problematic certainly does not mean that it is on equal footing with explicit racism, but we must nevertheless be aware that it might obscure the fact of lingering racist patterns. The reflected images of the triptych and the artwork by Makode Linde make such patterns traceable, at the same time as it reproduces them, albeit within ironic and critical frames.

\section{The (im)possibility of representing - speaking for whom?}

The Swedish writer Johannes Anyuru points to the fact that there is a material literalness in being black that no ironic play with representations can annul, thereby questioning naïve beliefs in the capacity of art (or free choice) to insulate itself from its context. ${ }^{33}$ Secondly, he emphasizes that Linde creates his work of art from a certainly colored, yet privileged position as middleclass inhabitant of Stockholm - and as a man, we might add.

Sometimes complexities can only be seen through simplifications. The way Sabuni and Anyuru indicts the artwork as racist recalls how Nigerian writer Chinua Achebe attacked Joseph Conrad's novel Heart of Darkness some 20 years ago, by pointing out that no matter how important and artistically sophisticated the novel's penetration into the heart of racist, white European culture might be, the blacks in the novel are all represented by racist stereotypes. This criticism was leveled without accepting any explanations about the novel being a child of its racist time. ${ }^{34} \mathrm{We}$ suggest that critique might need this element of simplifications, even as it regards Heart of Darkness as valuable. It is simply a sometimes indispensible mode of critique.

In lieu of this mode of critique, one neither has to defend oneself as white nor defend Western art. One could just accept its truth. To acknowledge one's privileges as white and to acknowledge the constitutive racism of Western culture does not necessarily imply a refusal to, for example, read Conrad. Instead, we have to learn to live with inescapable aporias of trying to read in this context. When Edward Said remarks that the novels of Jane Austen are both masterpieces and dependent on colonial racism, that at the same time as they describe pertinent moral issues to be learnt from, they still espouse a universal morality with colonial exploitation as its substratum, Said is engaging an embrace of ambiguity that opens the novels, enriches them. ${ }^{35}$

The important thing is not to judge and forbid, but to listen and read closely and attentively. First of all we have to read those that have not had a voice or a place within Western art. But we also have to learn to read "classic" artworks in ways that open them to other experiences and other sensibilities, and enriches them by seeing their foundational complications. Shakespeare's The Tempest is richer after readings that have revealed Caliban as a colonial victim. The way Said reads Austen makes racism visible and readable, and his reading changes us as well as Austen. Literature or art should not serve to enlist us in the fellowship of the good; they should affect and inspire reflection.

This discussion also has everything to do with Gayatri Spivak's statement that the kind of relativism pervading Western society 
actually has a lot in common with the fundamentalism it describes as its enemy. What unites them is their insistence on one's right to an opinion or belief regardless of the other. ${ }^{36}$ Of course one has a right to one's opinion, but this does not mean that one has the right not to listen to the other. ${ }^{37}$ If this aspect is missing we will not recognize the ambivalences and ambiguities that inhabit identities, norms and normality, goodness, and racism. Racism is entwined in our everyday lives, our history, our art, and literature. We, privileged whites, have to learn to read with the insight that racism is a part of our history, that we can relate to this history critically, without relativizing it or believing that we can relieve ourselves of it.

\section{The (im)possibility of living with paradoxes and ambivalences}

Gayatri Spivak's question "Can the subaltern speak?" is tremendously important here. As our triptych shows "we" are speaking, as researchers we are even paid to speak, and we are all white. One could very well question our right to speak, but our hope is that when we critically interpret what the artwork has done, with us and with others, something emerges that, perhaps in unforeseeable ways, might scrape the discourses of racism and sexism. We do not wish to decide whether an artwork is good or bad, racist or nonracist or sexist, whether the literal or ironic reading is correct (they probably deconstruct each other in productive ways), and the question whether it has accomplished anything has to be reformulated in terms that go beyond intentionality. At the very least the work has initiated some speech and thought (even as it remains caught in the impossibility of letting the subaltern speak).
The triptych and the reflections on it have to do with how to understand political agency, responsibility, and the possibilities and difficulties of critical art and thinking in neoliberal times. There might be "local and regional" resistance, even though the neoliberal medialandscape of today makes contestation hard, and even silences the subaltern in new ways. This is the situation we are in: having to reach for the impossible and accepting that there are no "real" representations, no ultimately "real" resistance, or, in short: the (im)possibility of a universalist resistance and critique - coupled with the possibility of "local and regional" resistance. Therefore, we continue to speak, continue to represent, letting the words and the images resonate, not in a relativist fashion of having the right to represent anyone, but in the impossible way of never having the possibility or the right to represent even oneself, and yet continuing to represent in this impossible fashion, trying to undo the one so that the other may come first. This is about an ethics of impossibility, not about being good. If we read carefully, maybe we can even see ourselves as the other's difference, letting the other emerge in an opening to the "silent gift" of the subaltern, as Spivak puts it. ${ }^{38}$

Since art is always entwined in contexts that impose its meaning upon it, it may have racist and sexist effects regardless of the artists' intentions. But art also questions and changes contexts, sometimes by putting viewers and readers in awkward positions, by making us feel ashamed and guilty - without the slightest possibility of turning these feelings into imaginaries of ourselves as good, dialectally cashing in on negativity. Through readings such as the one we have tried to undertake in this triptych, relations between agents are, hopefully, rendered traceable, visible, and readable. But folded shut, political 
art in a world without contention - obsessed with representations - risks commodifying and thingifying what is actually relational, thereby making it possible to turn social and political issues into matters of individual choice and opinion through responsibilization and individualization.

It is possible to argue that a "turning of relations into things" is symptomatic of neoliberalism, and thus our triptych analysis, opening the panels of the 'painful cake', has strived to turn things into relations. Taking such a perspective on the artwork, this 'thing' becomes an expression of the interconnections or relations between art and public media, on the one hand, and, on the other, the political terrain of noncontention as a defining characteristic of neoliberalism and, in particular, Swedish political life. The lack of significant social movement, actual stakes in politics, risks turning this kind of 'thing' into a non-thing, a mere media-spectacle and subsequent fingerpointing contest.

In discussing the new relationship between theory and practice emerging from the events of May '68, Foucault and Deleuze (1977) concluded that theory would no longer be totalizing and representational, but local and regional. Now, what happens when theory or, as in this case, an artwork, is not 'local and regional,' an intrinsic part of practice, but a distant representation of the media - because politically the artwork came to be a creation of the media and not of Makode Linde - is that it risks becoming part of power's totalizing drive, caught in representationalism, without real political meaning. Perhaps the political art project cannot be resumed in Sweden that is not soaked in popular contention, but remains dead until such a scenario materializes.

\section{Acknowledgements}

Our warmest thanks to Professor Gabriel Griffin for reading and discussing an early version of this article with us, inspiring us to continue with it. We would also like to thank all the researchers in Forum for gender studies for creative responses to our thoughts. The work with this article has been done in the research project "Normalization and the neoliberal welfare state. Challenges of and for gender theory" (Vetenskapsrådet, 344-2011-5104).

\section{Endnotes}

1. Pontus Raud, "Painful Cake", available at www.youtube. com/watch?v=rCK6zvWEN_Q (accessed 2014-8-21).

2. Johan Palme, "Makode Linde - The 'Swedish Cake' Artist Explains Himself”, 2012, available at http://africasacountry. com/africa-is-a-country-interview-with-makode-linde/ (accessed 2014-8-21).

3. Sander Gilman, "Black Bodies, White Bodies: Toward and Iconography of Female Sexuality in Late NineteenthCentury Art”, Critical Inquiry, No 1, 1985, pp. 204-242.

4. Caudette Carr, Barbara Mhangami and Samantha Asumadu, "An Open Letter from African Women to the Minister of Culture: The Venus Hottentot Cake", 2012, available at http://www.msafropolitan.com/2012/ 04/an-open-letter-from-african-women-to-the-minister-of-culture-the-venus-hottentot-cake.html (accessed 2014-8-21).

5. Lauren Berlant, Cruel Optimism, Durham, 2011, p. 3.

6. Theodor Adorno, Aesthetic Theory, London, 1997, p. 298; Pierre Bourdieu, The Rules of Art. Genesis and Structure of the Literary Field, Stanford, 1995, pp. 81-84.

7. Michael McEachrane in Beth Maina Ahlberg, Claudette Carr, Madubuko Diakité, Fatima El-Tayeb, Tobias Hübinette, Mamodou Jallow, Victoria Kawesa, Michael McEachrane, Utz McKnight, Anders Neergaard, Shailja Patel, Kitimbwa Sabuni and Minna Salami, "Racism Is No Joke: A Swedish Minister and a Hottentot Venus Cake - An Email Conversation". in Michael McEachrane (ed.), Afro-Nordic Landscapes. Equality and Race in Northern Europe, New York, 2014, pp. 120-148.

8. Kitimbwa Sabuni, “Avgå, Adelsohn Liljeroth”, 2012, available at http://www.aftonbladet.se/debatt/article14691302ab. (accessed 2014-8-21).

9. Bronwyn Davies and Susanne Gordon, Doing Collective Biography. Investigating the Production of Subjectivity, Maidenhead, 2006, pp. 3-4.

10. Annette Stott, "Transformative Triptychs in Multicultural America”, Art Journal, No 1, 1998, pp. 55-63. 
11. C. Crais and P. Scully, Sara Baartman and The Hottentot Venus. A Ghost Story and a Biography, av Clifton Princeton and Oxford, 2009, pp. 1-6.

12. Maria Nikolajeva, "Matens Mytiska Dimensioner". in Ulla Bergstrand and Maria Nikolajeva (eds.), Läckergommarnas Kungarike. Om Matens Roll i Barnlitteraturen, Stockholm, 1999, p. 35.

13. bell hooks, "Att Äta den Andre: Begär och Motstånd”. in Thomas Johansson, Ove Sernhede and Mats Trondman (eds.), Samtidskultur. Karooke, Karnevaler och Kulturella Koder, Nora, 1999, p. 169.

14. hooks, 1999, p. 173.

15. Åsa Ljungström, "Kaffe, klass och kön - jämlikhetens dryck i Millennium-trilogin". in Siv Fahlgren, Anders Johansson and Eva Söderberg (eds.), Millennium - Åtta genusvetenskapliga läsningar av den svenska välfärdsstaten genom Stieg Larssons Millennium-trilogi, Sundsvall, Genusstudier vid Mittuniversitetet, Rapport 4 2013, p. 97-120.

16. Garrath Williams, "Blame and Responsibility", Ethical Theory and Moral Practice, No 4, 2003, pp. 427-445.

17. Maria Carbin and Malin Rönnblom, "Jämställdhet i Akademin: En Avpolitiserad Politik?”, Tidskrift för Genusvetenskap, No 1-2, 2012, pp. 75-94; Williams, 2003, p. 404.

18. Eve Kosofsky Sedgwick, Touching Feeling. Affect, Pedagogy, Performativity, Durkham and London, 2003, p. 62.

19. Maria Jönsson, “Att Väcka Anstöt: Om Äckel, Genans och Obehag i Mottagandet av Kerstin Thorvalls Författarskap". in Annelie Brännström Öhman, Maria Jönsson and Ingeborg Svensson (eds.), Att Känna Sig Fram. Känslor i Humanistisk Samhällsforskning, Umeå, 2011, pp. 45-65.

20. Sarah Ahmed, "A Phenomenology of Whiteness", Feminist Theory, No 2, 2007. p 156.

21. Sarah Ahmed, The Cultural Politics of Emotion, Edinburgh, 2004, p. 174.

22. Williams, 2003, pp. 427-445.

23. Gayatri Chakravorty Spivak in Mikaela Lundahl (ed.) "Kan den Subalterna Tala?" in Postkoloniala Studier, Stockholm, 2002, pp. 31-72.

24. Spivak, 2002, p. $125 \mathrm{ff}$.

25. Shailja Patel, “The Missing Ingredient in Sweden's Racist Misogynist Cake", 2012, available at http://www.pambazuka.org/en/category/features/81491 (accessed 2014-8-21).

26. Gayatri Chakravorty Spivak, In Other Worlds: Essays in Cultural Politics. New York; London, 1988, p. 205.

27. Natasha Gordon-Chipembere, From Silence to Speech, from Object to Subject. The Body Politic Investigated in the Trajectory between Sarah Baartman and Contemporary Circumcised African Women's Writing, Pretoria, 2006.
28. Sarah Ahmed, "Declarations of Whiteness: The NonPerformativity of Anti-Racism", Borderlands E-Journal, No 2, 2006, available at http://www.borderlands.net.au/ vol3no2_2004/ahmed_declarations.htm (accessed 201411-21).

29. Paulina de los Reyes and Satu Gröndahl, "Introduktion". in Paulina de los Reyes and Satu Gröndhl (eds.), Framtidens Feminismer. Intersektionella Interventioner $i$ den Feministiska Debatten, Hägersten, pp. 11-24.

30. Sabuni, 2012.

31. Ahmed, 2006.

32. Elizabeth A. Povinelli, "The State of Shame: Australian Multiculturalism and the Crisis of Indigenous Citizenship", in Lauren Berlant (ed.), Intimacy, Chicago, 2000, pp. 253-288.

33. Johannes Anyuru, "Lena Adelsohn Liljeroth \& Tupacs Vålnad”, Glänta, No 2-3, 2012, pp. 9ff.

34. Chinua Achebe, "An Image of Africa: Racism in Conrad's 'Heart of Darkness"', in Robert Kimbrough (ed.), Heart of Darkness. An Authoritative Text, Backgrounds and Sources, Criticism, New York, 1988, pp. 251-261.

35. Edward W. Said, Culture and Imperialism, New York, 1993, pp. 115-116.

36. Gayatri Chakravorty Spivak, Outside in the Reaching Machine, London, 1993.

37. Siv Fahlgren and Anders Johansson, "Reading Normalised Knowledge Production from a Feminist Perspective - a Case Study", The IARTEM eJournal, No 1, 2010, pp. 25-45.

38. Gayatri Chakravorty Spivak, "Translator's Preface and Afterword to Mahasweta Devi's Imaginary Maps", in Donna Landry and Gerald MacLean (eds.), The Spivak Reader. Selected Works of Gayatri Chakravorty Spivak, New York, 1996, pp. 271-277.

\section{Summary}

On the 15th of April, 2012, The Modern Museum (Modernamuseet) in Stockholm celebrated the World Art Day by having a reception with the Swedish cultural minister present, at which an artwork in the form of a cake made in the likeness of the body of a caricatured black woman was served, cut up and eaten, while the artist, masked as the cakes head, screamed. This conceptual, relational, and contextualizing artwork, which leads to a much heated debate in Sweden and which was also internationally picked up on, 
was made by the explicitly anti-racist artist Makode Linde. In this article, we explore the problem of this event in terms of its sociocultural significance. How did we react upon the drama that we were following from a distance? What did it make us see? What questions did the incident raise about the Swedish society of today? These are examples of the questions we as gender researchers working in Sweden will discuss in the form of a triptych. We use the triptych metaphor as a tool for opening dialogue. By opening its panels it becomes possible to decommodify the single image of the artwork and make relations between agents traceable, visible, and readable.

\section{Siv Fahlgren}

Department of Social Sciences

Mid Sweden University

85170 Sundsvall

Sweden

E-mail: Siv.fahlgren@miun.se

Katarina Giritli Nygren

Department of Social Sciences
Mid Sweden University

85170 Sundsvall

Sweden

E-mail: katarina.giritli-nygren@miun.se

Magnus Granberg

Department of Social Sciences

Mid Sweden University

85170 Sundsvall

Sweden

E-mail: magnus.granberg@miun.se

Anders Johansson

Department of Humanities

Mid Sweden University

87188 Härnösand

Sweden

Email: anders.johansson@miun.se

Eva Söderberg

Department of Humanities

Mid Sweden University

87188 Härnösand

Sweden

E-mail: eva.soderberg@miun.se 